\title{
Entrepreneurship Education: \\ Engineering a Pracademic Approach
}

M.D. Wilson, Eric Holloway, Dr. Monica Cox, \& Molly Goldstein

Purdue University

wilsonmd@purdue.edu; eahollow@purdue.edu; mfc@purdue.edu; goldstm@purdue.edu

S. Jimmy Gandhi

California State University, Northridge

sj.gandhi@csun.edu

\begin{abstract}
Innovation and entrepreneurship are becoming increasingly important as we rely on economies to create jobs around the globe. And yet, considering the myriad and dynamic business environments of the $21^{\text {st }}$ century and ever increasing consumer power, the risk of entrepreneurial activity has increased considerably. Consequently, we need to educate engineers in an innovative manner and fundamentally change the teaching methods, curriculum, and research in entrepreneurship education. Applying the scholarship of teaching and learning (SoTL) to entrepreneurship with similar rigor can increase the odds of being successful engineering entrepreneurs. Still, faculty and administrators of engineering programs are hesitant to introduce courses into an engineering curriculum outside of engineering fundaments. The paradox, however, is that non-core engineering courses including leadership and engineering management can help students develop highly desired attributes that contribute to career and industry success.
\end{abstract}

In this paper, the authors look at current trends in entrepreneurship education and will propose a potential new approach to innovation and entrepreneurship education for engineers in the 21st century. This approach will focus on pracademic (practical / professional and academic) learning concepts that are both engaging and worthwhile for student-centered learning. Supplementary pedagogical approaches are necessary to augment classroom learning for aligning active-learning topics within innovative course frameworks. This new approach will focus on four topics: innovation in teaching methods, introducing leadership education into the entrepreneurship curriculum, quality within systems engineering management, and using rigorous research to drive transformational change in entrepreneurship education. The pracademic approach will be taught as a workshop series or as courses in the entrepreneurship domain and will be presented as part of this paper where methods, leadership, quality, and rigorous research are the central tenets the authors propose for serious and thrivable consideration.

Keywords: entrepreneurship, innovation, engineering education, pracademic, thrivability

\section{Current trends in entrepreneurship education}

Currently entrepreneurial engineering programs at the undergraduate level combine the basic technical knowledge that students have with topics that are considered essential for entrepreneurship such as accounting, finance, leadership, intellectual property and marketing. This helps the undergraduate students understand the basics of 
entrepreneurship during the formative years of their engineering education (AlRomiah et al., 2013). At the graduate level, several engineering programs incorporate prescriptive entrepreneurship subjects such as technology needs assessment, road mapping, planning, risk management, etc. ${ }^{1}$

Traditional forms of current entrepreneurship teaching classifications include the following methods, approaches, and pedagogies:

Table 1: ${ }^{2}$ Summary of Entrepreneurship Teaching and Learning Methods

\begin{tabular}{|c|c|c|}
\hline Teaching Method & Learning Method & Example Sources \\
\hline Case Studies & Experiential Learning & \multirow{3}{*}{$\begin{array}{c}\text { (Garcia et al., 2012; Kent, } \\
\text { 1990; Klatt, 1988; Vesper, } \\
\text { 1985) }\end{array}$} \\
\hline Writing Business Plans & Experiential Learning & \\
\hline $\begin{array}{c}\text { Lectures by Business } \\
\text { Owners or Entrepreneurs }\end{array}$ & Didactic Learning & \\
\hline Traditional Lecture & Didactic Learning & Standard Education Model \\
\hline Computer Simulation & Experiential Learning & $\begin{array}{c}\text { (Brewer, Anyansi- } \\
\text { Archibong, \& Ugboro, } \\
\text { 1993) }\end{array}$ \\
\hline Student Clubs & $\begin{array}{c}\text { Pseudo- Experiential } \\
\text { Learning }\end{array}$ & Standard Education Model \\
\hline Research Projects & $\begin{array}{c}\text { Pseudo- Experiential } \\
\text { Learning }\end{array}$ & (Aldrich, 2012) \\
\hline Internships & Experiential Learning & $\begin{array}{c}\text { (Korotov, Khapova, \& } \\
\text { Arthur, 2011) }\end{array}$ \\
\hline $\begin{array}{c}\text { MEAs (Model-Eliciting } \\
\text { Activities) }\end{array}$ & Experiential Learning & (Siewiorek et al., 2010) \\
\hline
\end{tabular}

A typical approach to entrepreneurship education in a university setting is to leverage existing business courses and other courses already offered at the university to offer a "minor or certificate" in entrepreneurship, innovation, or both. One example includes the "Certificate in Entrepreneurship and Innovation Program" offered at a large research university in the Midwest. In this program, to receive a certificate, participating students must take the equivalent of five, 3-credit courses as outlined in the table below.

This approach to entrepreneurship education (leveraging existing university courses and resources) makes sense for starting new programs, as the programs can typically be implemented quickly with little controversy or initial bureaucracy. Yet, for real innovation to occur, additional steps need to be taken. Real innovation in education occurs when faculty and administrators consider new ways and new methods of teaching, consider implementing new experiences, and focus on learning concepts that are both engaging and worthwhile. Another common approach is to use a pracademic, someone who has both academic prowess and practical, professional experience. Typically an industry professional returns to academia to either impart knowledge through research or in teaching and sharing in the classroom. The pracademic often brings industry 
Table 2: Summary of Certificate in Entrepreneurship and Innovation Program

\begin{tabular}{|c|c|}
\hline Program Courses/Credit Hours & Details \\
\hline Two required "core" courses (6 credits) & $\begin{array}{l}\text { The intent of required core courses is to } \\
\text { provide students with fundamental language, } \\
\text { knowledge, leadership, and communication } \\
\text { skills related to entrepreneurship and } \\
\text { innovation. The content in these courses } \\
\text { answer the questions "what is } \\
\text { entrepreneurship" and "how do you do } \\
\text { entrepreneurship." Solely the Certificate in } \\
\text { Entrepreneurship and Innovation offers } \\
\text { required core courses. }\end{array}$ \\
\hline $\begin{array}{c}\text { Two "option" courses (typically } 6 \\
\text { credits) }\end{array}$ & $\begin{array}{l}\text { The intent of option courses is to provide } \\
\text { students with discipline or industry/market- } \\
\text { specific depth in areas, which are relevant to } \\
\text { entrepreneurship and/or innovation. } \\
\text { Departments offer option courses across the } \\
\text { university as well as by the Certificate in } \\
\text { Entrepreneurship and Innovation. }\end{array}$ \\
\hline $\begin{array}{l}\text { One "capstone" course or experience } \\
\text { (typically } 3 \text { credits) }\end{array}$ & $\begin{array}{l}\text { The intent of capstone courses or experiences } \\
\text { is to provide students with hands-on, real- } \\
\text { world entrepreneurial or innovation related } \\
\text { experiences, which can include developing } \\
\text { business plans for new business ventures, } \\
\text { involvement in the product innovation and } \\
\text { technology commercialization process, or an } \\
\text { approved internship in an early-stage } \\
\text { company. Capstone courses and experiential } \\
\text { programs are offered by departments across } \\
\text { the university as well as by the Certificate in } \\
\text { Entrepreneurship and Innovation }\end{array}$ \\
\hline
\end{tabular}

Source: http://www.purdue.edu/discoverypark/entr/academics/requirements.php

experience in dealing with uncertainty, ambiguous assignments, limited resources, and constant design constraint; translating such esoteric elements is both hard to teach and even trickier to assess but a pracademic often conveys through a combination of hands-on experiential lessons. Making innovative discoveries is not merely routine-oriented, there exists idiosyncrasies, but the process is potentially teachable for wealth creation. Further, the pracademic (with entrepreneurial experiences) prescribes stepwise processes designed for "building knowledge structures"3; constructionism, then, is a concept that goes beyond learning-by-making and is the pre-cursor to project-based-learning (PBL) from which the engineering pracademic relies.

Yet as time passes, the call for Engineering Entrepreneurship Education is wide but varied. Recently there have been calls to also make engineers possess design, technical 
competency, innovative, and more entrepreneurial skills ${ }^{4}$. Entrepreneurship via 'innovation' is also the siren call made by the National Academy of Engineering in both its 2005 report as well as in Educating the Engineer of $2020^{5}$. How engineers do innovation might translate to a teachable tactic.

\section{Innovative Teaching Methods and Topics}

Historically, students' participation in college classrooms is passive, where "learning appears to be a 'spectator sport' in which faculty talk dominates"6, and where there are few active student participants ${ }^{7}$. Interestingly, both Fassinger ${ }^{8}$ and Nunn $^{9}$ found decades ago that classroom traits, specifically a supportive atmosphere, are as important to student participation as are student and faculty traits. This is a significant finding for entrepreneurship education, as entrepreneurship requires a certain mindset to be successful, and a supportive atmosphere best nurtures this mindset. In such a context, there is "a growing recognition that student learning is enhanced when students are actively involved in learning and when they are placed in situations in which they have to share learning in some positive, connected manner" ${ }^{10}$. Introducing supplemental learning opportunities can lead to increased student engagement and increased learning. Further, evidence-based teaching is most effective when students are actively engaged in the process and receive feedback while learning.

The idea for using "Think Aloud” teaching tactics was formally confirmed while at a Colloquium at the University of Kentucky on International Engineering Education where the presenter learned of a colleague, Dr. Thomas Hope, applying the pseudo-experimental idea of discussing topics over lunch with students on an open-invitation but voluntary basis, (http://www.ipo.titech.ac.jp/english/ics/page14/page14.html), ${ }^{11}$ at the Tokyo Institute of Technology. Similarly, another presenter-author has also long invoked a tradition of "coffeehouse chat" discussions with students after lectures as well. In addition, Professor Hope christened and implemented the "Think Aloud" tradition at the Tokyo Institute. The idea is that students show up to discuss topics on their mind and on their own volition. In this capacity, classroom topics are discussed over lunch in an informal setting and participate as peers rather than mere students. As well, coffeehouse chats remove the dogma of in the box learning for students to share openly. In fact during the colloquium considering engineering education, a panel of industry representatives indicated that the best way to interview and recruit a candidate is informally over lunch; noting that is where real attributes are displayed. Supplemental learning environments, while not formally assessed in academia explicitly or expressly, matter. Moreover, theories are strewn to world topics and dissected for the timeliness and realness affecting the globe at-large. The majority of discussions are not surprisingly, "metaentrepreneurial” in nature and in context. This suggests that outside activities might provide student learning or outcome potential if researched affectively. Student engagement is an initial springboard to investigating and reflecting further metacognitive concepts to influencing pedagogy.

Another tactic resides in the "Mini Assignment" offering. This method began as a quasipunishment for missing class or for non-performance of a homework assignment by a 
current author. However, the idea quickly took off to the point of students volunteering and asking to present. A "Mini" as the tactic has become known colloquially, centers on an individual student researching a topic theory or term, and often a curve-ball topic is intermeshed by the professor, for example, the acronym SCRUM within the Project Management Body of Knowledge (PMBOK) is assigned along the latest, popular App "SnapChat" phenomenon; and then using a technology presentation tool (Prezi, YouTube, Haiku-Deck, or PowerPoint) of their choosing, the student conveys a fiveminute presentation synthesis on the term, concept, or idea with the end-deliverable mandating that it tie-in with a so-what connection to the course material. The advent of the "Mini" then operates individually the way Think-Pair-Share (TPS) functions for groups, creating excitement, in the How People Learn (HPL) educative format ${ }^{12}$. Such efforts often transform and translate actual or real-world industry concepts to academic experiences. With an individual investment of a "Mini" the ownership is conveyed as well as heightens competiveness for the student responsibility in "teaching" and transferring the timely information. The reverse approach of student turned teacher allows for the professor to measure the peer teaching conveyance from the individual and to the class at-large. We know from educational research that peer learning is statistically more successful than lecture learning especially around "hard" concepts in the sciences ${ }^{13}$.

Evidence also shows while the prevalently used method lecture-based teaching still exists and dominates classrooms that the teaching tactic is ineffective for student learning ${ }^{13}$. Conversely, evidence for the innovative Flipped Peer Instruction model was famously introduced by Eric Mazur ${ }^{14}$, a physics professor at Harvard, who implemented a form of teaching called "Peer Instruction." Students learn the material before class, and then the instructor asks a series of conceptual multiple-choice questions in class. The instructor puts up the first question, students then answer it and share their answer with the instructor without talking to any of their peers. Then students discuss their answers with their peers and try to convince their peers of their answer. The students with the correct answers are typically able to convince their peers who had the wrong answer of what the right answer is and why. Innovation in teaching when using "Think Aloud", Miniassignments, or Peer/Flipped instruction empowers students through professor engagement. Entrepreneurship courses demand innovative approaches allowing students to become knowledge-able over knowledgeable. ${ }^{15}$

\section{Introducing Leadership Education into the Entrepreneurship Curriculum}

Leadership education is often seen as an optional requirement, rather than as an essential requirement for entrepreneurial education. As seen in the earlier analysis of this paper, entrepreneurial programs in higher education are typically built by combining already existing curricula together, along with developing one or two new courses in entrepreneurship. Typically, students can pursue leadership education as an optional tract with an entrepreneurial program, as presented and documented at the large research university in the Midwest studied in this paper. However, research shows that leadership and entrepreneurship are intrinsically linked. In Vecchio's analysis comparing entrepreneurship and leadership, Entrepreneurship and Leadership: Common Trends and 
Common Threads ${ }^{16}$, he looks at the scholarly fields of entrepreneurship and leadership in depth, including much published research, and comes to the following stark conclusions:

1. "many of the constructs used in the area of entrepreneurship are also found within the mainstream of leadership theory" (pg 322). ${ }^{16}$

2. “entrepreneurship is leadership within a narrow, specific content” (pg 322). ${ }^{16}$

3. "it is more cogent and parsimonious to view entrepreneurship as simply a type of leadership that occurs in a specific setting" (pg 322). ${ }^{16}$

Vecchio also argues that that leadership can be effectively taught, but also has to be experienced. He states that leadership can be taught "for certain aspects of leadership (such as appreciation of obstacles, an awareness of different role models, and knowledge of frameworks for understanding/interpreting social processes" and experienced "for certain aspects of leadership that are more situation-specific (such as whether to undertake a personal "makeover”, to challenge one's own supervisor, or to join toastmasters)." 16 The implications of an entrepreneurial education are clear: Leadership and entrepreneurship are intrinsically linked, and because leadership education can be effective when taught through a combination of theory and experience, introducing leadership education into the entrepreneurship curriculum must transition from an optional tract to a required tract.

\section{Quality for Engineering Management}

As a result of delimiting course-offerings, a critical component that is left out of the engineering entrepreneurial curriculum is the inclusion of quality management topics such as understanding the customer, which is important for students to understand in order to be able to do entrepreneurship well ${ }^{17}$. This was also experienced by one of the authors of this paper, who teaches courses in quality management as well as entrepreneurship. The author realized the students in his class were unprepared to make a business plan due to unawareness of topics related to quality management. Indeed, as Streveler and others note, "topics might include learning where and how to collect important business intelligence necessary to create a business plan, as well as the essential elements for producing a viable business plan"; for determining important to know items such as, "what are the few critical actions or understandings - at a tactical level, that my students must take with them from the class?” is both salient and vital. ${ }^{18}$ Further this prompted the authors to start the discussion about incorporating aspects of out-of-classroom elements as well as quality, one author's sub-specialties', into the entrepreneurship education for engineers and was central to the motivation behind starting this research.

For starters, entrepreneurs need to think both innovatively and inquisitively. These two qualities go hand in hand and are complementary to each other, i.e., being inquisitive in the right manner could help an engineer to be innovative. When engineers are going through the innovation process, they should learn to ask questions such as: 
- What are the functionalities the customer wants?

- What are the capabilities of the current product/service?

- What are the limitations of the material/actions we have selected?

- Are there better materials/options available?

- How much will the product cost to make?

- How much must the product cost to make it successful in the marketplace?

- Who is the target market for this product? And why produce or service?

Answering these questions increases the probability of an engineer becoming a successful entrepreneur ${ }^{19}$. However, the key is to be able to research in the right way to be able to rigorously answer the above questions, thereby increasing the odds of being a successful entrepreneur. In order to be able to research effectively, several concepts of quality management should be understood by engineers. This includes topics such as Collecting Data on Customer Expectations, Voice of the Customer (VoC), Quality Function Deployment (QFD), as well as The House of Quality, which helps an engineer better understand a means for implementing customer needs into functional design ${ }^{20}$. Quality Function Deployment (QFD) is often thought of by quality professionals as a tool to understand 'your' customer needs and thus help the organization satisfy or even delight the customer, which is a necessity to being a successful entrepreneur and making 'your' business flourish on a long term basis. The primary function of the QFD is to effectively listen to the voice of the customer and then respond to those needs and expectations. In order to listen to the voice of the customer, details are captured using several methods: direct discussion, interviews, surveys, focus groups, customer specifications and warranty data. To be sure, it is important to keep in mind that there is no one "version" of the voice of customer. Customer voices are diverse and will vary depending on the need and also the type(s) of customer(s) involved. Such an understanding of customer needs is then summarized in the "House of Quality." This "house of quality" is used to translate higher level what's or needs into lower level how's or product requirements or technical characteristics to satisfy these needs. It is for this reason that the authors feel that concepts such as QFD should be incorporated into entrepreneurship education, particularly for engineers.

Additionally, engineers also need to understand a new concept called "Thrivability," which is simply defined, as the "ability to thrive," but is an extremely complex phenomenon that cannot be grasped easily. Thrivability emerges from each person holding the persistent intention to be generative: that is to create more value than we consume. ${ }^{21}$ When practiced over time, this builds a world of ever-increasing possibilities, which is an important aspect of being an innovative society.

Understanding the risks associated with your product and overall project is also a key part of being an entrepreneur. It is important to understand risk from a systemic perspective. ${ }^{22}$ This means that all the components of the risks should be understood as well as the interconnectedness between those components. The external factors that could affect the risks associated with your product should be considered, when thinking about risks from a systemic perspective. Entrepreneurs need to be aware that they operate in a global 
environment, and hence need to think about their project from a systemic perspective and an understanding of systems thinking can greatly help.

Moreover, sustainability in engineering projects is an extremely important phenomenon, since a sustainable business is an enterprise that has a positive net impact on the global and local environment as well as the social and economic spheres. It can be thought of as a business that strives to meet the triple bottom line. Many national manufacturing brands such as Ben and Jerry's ice cream, Stonyfield yogurt, and Tom's of Maine products follow the triple mission three-part model of distinct but interrelated economic, social, and product missions. Often, sustainable businesses have progressive environmental and human rights policies. ${ }^{23}$ Engineers who are involved in entrepreneurship need to understand that there is no alternative to sustainable development. ${ }^{24}$ This is a revolutionary understanding that needs to be accepted throughout the industry. A large percentage of companies are convinced that the more they implement sustainability, the more it will erode their competitiveness. Conversely, the key for entrepreneurs is to understand that this is a misconception. There have been several examples in recent times, which demonstrate that sustainability could be a competitive advantage by virtue of cost savings that can be leveraged by engineering firms and thus can increase the odds of an entrepreneur being successful.

\section{Rigorous Research in Entrepreneurship Education}

Lastly, entrepreneurs need to understand the benefits of research and that the evolution of the global economy has brought forth a competitive worldwide marketplace whereas delivering the benefits of reduced labor costs and lower operating expenditures, which could directly affect the product they are developing. ${ }^{25}$ Indeed, the lack of rigorous research regarding curriculum is both fracturing (among scholars) and frustrating (among students/professionals). There exist little curricula within academia that the "soft" skills of entrepreneurship (e.g. creativity, leading teams, life-long learning) are viewed as important as scientific instruction and thus remain tepid to merging entrepreneurship classes within engineering disciplines. Though emerging literature suggests that teaching entrepreneurship is an especially effective tool for engineering students because "they have to think and express themselves with different representational methods, namely the written and spoken word, as opposed to merely numerical representation methods that lend themselves almost exclusively to mathematical algorithms." ${ }^{26}$ The entrepreneurial literacy gap for STEM majors, specifically engineering students, remains vast and extremely complex.

Entrepreneurship education is ripe for innovative change by following the lead of the engineering education community. Engineering education, and specifically engineering education research, is in a period of rapid and profound change, driven by the one constant in the history of educating engineers in the United States: the call for change. ${ }^{27}$ Over the years, this call for change has manifested itself in several transformational ways: the Morrill Act in 1862 made engineering more accessible to the masses; the launch of Sputnik in 1957 helped bring the engineering sciences into the undergraduate curriculum; and more recently, ABET's adoption of the Engineering Criteria 2000 (EC2000) in 1997 
shifted the focus of undergraduate engineering education to student outcomes from the specifics of the curriculum taught.

Today, there is a call for change in the ways engineers are educated continues, demonstrated by the National Academy of Engineering's (NAE's) report The Engineer of $2020^{28}$ and the American Society of Engineering Education's (ASEE's) report Innovation with Impact. ${ }^{29}$ One of the strongest calls for change has come from The Steering Committee of the National Engineering Education Research Colloquies, which calls for "a transformational change rather than incremental improvements in how we recruit and educate engineering students" 30 using "a rigorous research-based approach.” Academia is responding to these recent calls for change by adopting the "rigorous research-based approach" in engineering education. Universities such as Purdue University and Virginia Tech University have implemented engineering education programs, as example, that are performing rigorous research, and many other universities are following this trend.

An argument can be made that engineering education, driven by rigorous research, is in the midst of transformation change once again. The breadth of engineering education research is profound, including the following five main areas: engineering epistemologies, engineering learning mechanisms, engineering learning systems, engineering diversity and inclusiveness, and engineering assessment. ${ }^{30}$ The impact of this research is driving innovative change, as the research is affecting change in policy, teaching methods, curriculum, student recruitment and retention, and student/faculty interactions, just to name a few. In addition, the research is driving new curricular discussions on the existing engineering curriculum to include, as the authors purport: leadership, global engineering, and sustainability. Even more important, the days of making educational changes by intuition and trial and error are becoming a thing of the past, replaced by rigorous research to help educators and administrators make informed choices. Yet one area where rigorous research is lacking remains in the cannon of entrepreneurship education.

Entrepreneurship education, for the most part, has been driven primarily by intuition and integration of existing business courses into the curriculum. By following the lead of engineering education, entrepreneurship education can be innovatively transformed by inculcating rigorous research. In fact, the authors recommended that entrepreneurship education research be performed within the engineering education research community, which has a rich tradition of being multi-disciplinary and reaching across disciplines to bring real collaboration to academic research. The long history of the call for change in engineering education can also be leveraged to make similar profound and innovative changes in entrepreneurship education by echoing the proven method of rigorous research to inform entrepreneurial decisions.

\section{Conclusion: How entrepreneurship should be taught to engineering students}

The authors recommend that the traditional entrepreneurship curriculum needs to be modified with several additions. The primary topics that need to be added or incorporated into the entrepreneurship curriculum include: 
(a) Innovative methods for supplemental (Pseudo-Experiential Learning) reach using out-of-class Pracademic forums and in-class peer-instruction.

(b) Quality Management, which includes topics such as The Voice of Customer, Quality Function Deployment (QFD) and The House of Quality.

(c) Thrivability, which would help engineers to envision new alternatives and think more intuitively, with human-optimal considerations above pure optimization.

(d) Risk Management from a systemic perspective for Sustainability and Globalization.

(e) Adopting rigorous research in the emerging field of Entrepreneurship Education.

In the past two decades, entrepreneurship education has gained a foothold in engineering education, and the authors believe that trend will continue to grow as more students seek to become entrepreneurs. Accordingly, as entrepreneurship education continues to grow, the status quo of combining already existing curricula together along with developing one or two new courses in entrepreneurship will no longer suffice. It is time for innovative change to embed entrepreneurship education.

Thus, we have proposed innovative change by combining four core concepts: innovation in teaching methods, introducing leadership education into the entrepreneurship curriculum, applying Quality concepts for engineers learning entrepreneurship, and using rigorous research to drive transformational change. Combined, such aforementioned changes can have a transformative impact, both scholarly and societal, for future engineers to learn, experience, and practice.

The authors believe that an understanding of the above topics could greatly help the United States and other progressive countries produce entrepreneurs for the $21^{\text {st }}$ century who could meet the challenges of introducing new products or services into today's dynamic and global business environs.

\section{Bibliography}

1 Al Romaih, Nasser; M. Rajai \& S.J. Gandhi, “An Innovative Approach to Educating Engineers in Entrepreneurship,” Proceedings of The 2013 American Society for Engineering Education, Pacific Southwest Conference, Pomona, CA, April 18-20, 2013.

2 Goldstein, M. (2013), "Engineering Entrepreneurship Education Climate and Current Trends: A Literature Synthesis,” White Paper at Purdue University, pp. 2-11.

3 Papert, S., and Harel, I. (1991), Constructionism, Ablex Publishing, Norwood, New Jersey.

4 Bollfrass, C., Designing innovative engineers, Hart’s E\&P, 81(10), 2008, pp. 94. 
5 National Academy of Engineering. (2004 and 2005). The engineer of 2020: visions of engineering in the new century: National Academy Press.

6 Fischer, C. G., \& Grant, G. E. (1983). Intellectual levels in college classrooms. In C. L. Ellner \& C. P. Barnes (Eds.), Studies of college teaching (pp. 47-60). Lexington, MA: D.C. Heath.

7 Smith, D. G. (1983). Instruction and outcomes in an undergraduate setting. In C. L. Ellner \& C. P. Barnes (Eds.), Studies in college teaching (pp. 83-116). Lexington, MA: D.C. Heath.

8 Fassinger, P. A. (1995). Understanding classroom interaction: Students' and professors' contribution to students' silence. Journal of Higher Education, 66, 82-96.

9 Nunn, C. E. (1996). Discussion in the college classroom. Journal of Higher Education, 67, 243-266.

10 Astin, A. (1984). Student involvement: A developmental theory for higher education. Journal of College Student Personnel, 25, 297-308.

11 Hope, T. (2013), http://www.ipo.titech.ac.jp/english/ics/page14/page14.html, at the Tokyo Institute of Technology.

12 Radhakrishna, Rama; Ewing, John; Chikthimmah, Naveen; Hoover, Tracy, Teaching Tips/Notes, NACTA Journal; Jun2010, Vol. 54 Issue 2, p57.

13 Smith, K., Sheppard, S., Johnson, D., Johnson, R. (2005) Pedagogies of Engagement: ClassroomBased Practices, Journal of Engineering Education (JEE), January, (pp. 87-99).

14 Mazur, E., (1997), Peer Instruction: A User’s Manual, Prentice Hall, Saddle River, NJ.

15 Wesch, Michael (2009), Tedx Talk: “From Knowledgeable to Knowledge-able,” KS: http://www.youtube.com/watch?v=LeaAHv4UTI8

16 Vecchio, R. P. (2003). Entrepreneurship and Leadership: Common Trends and Common Threads. Human Resource Management Review, 13(2), 303-327.

17 Hall, Alan, “To Succeed as an Entrepreneur, Know Your Customer," Forbes Magazine, June 14, 2012, http://www.forbes.com/sites/alanhall/2012/06/14/to-succeed-as-an-entrepreneur-know-your-customer/ ; Accessed on January 2, 2013.

18 Streveler, R., Smith, K., Pilotte, M., (2012), Aligning Course Content, Assessment, and Delivery: Creating a Context for Outcome-Based Education, Information Science Reference, Hershey, PA, pp. 225.

19 Tan, Lay Leng, “Can a University turn an engineer into an entrepreneur?” Innovation Magazine, Volume 12, No. 1.

20 Pyzdek, Thomas \& Paul Keller, “The Handbook for Quality Management: A complete Guide to Operational Excellence,” McGraw Hill Publications, $2^{\text {nd }}$ edition, Published in 2013, ISBN: 978-0-07179924-9.

21 Russell, Jean, “Thrivability: Breaking Through to a World That Works,” Triarchy Press, 2013, ISBN: 978-1909470286.

22 Gandhi, Shereazad Jimmy, Alex Gorod, Brian Sauser, "Prioritization of outsourcing risks from a systemic perspective,” Strategic Outsourcing: An International Journal, Volume 5, Issue 1, 2012, pp. 39-71.

23 Diesendorf, Mark, “Sustainability and Sustainable Development,” Published by Sustainability Center Pvt Ltd, 2000. 
24 Nidumolu, Ram, C.K. Prahalad and M.R. Rangaswami, "Why Sustainability Is Now the Key Driver of Innovation", Harvard Business Review (2009), September 2009, pp 1-10.

25 Gandhi, Shereazad Jimmy, Christine Bullen, “Getting an Education in Global Sourcing,” 2011 American Society of Engineering Management (ASEM) International Annual Conference, October 2011.

26 Garcia, J., Sinfield, J., Yadav, A., \& Adams, R. (2012). Learning Through Entrepreneurially Oriented Case-Based Instruction*. International Journal of Engineering Education, 28(2), 448-457.

27 Seely, B. E. (1999). The Other Re- engineering of Engineering Education, 1900-1965. Journal of Engineering Education, 88(3), 285-294.

28 National Academy of Engineering. (2004 and 2005). The engineer of 2020: visions of engineering in the new century: National Academy Press.

29 Jamieson, L. H., \& Lohmann, J. R. (2012). Creating a Culture for Scholarly and Systematic Innovation in Engineering Education: Ensuring US engineering has the right people with the right talent for a global society. American Society of Engineering Educators (ASEE).

30 The Steering Committee of the National Engineering Education Research Colloquies. 2006a. The national engineering education research colloquies (Special Report). Journal of Engineering Education 95 (4):257-58. 